\title{
Editorial on the research topic : celebrating 100 years of modern fisheries science research in Korea
}

\author{
Kyoungmi Won ${ }^{1, *}$, Yeonghye Kim ${ }^{2, *}$ \\ ${ }^{1}$ Research Planning Division, National Institute of Fisheries Science, Busan 46083, Korea \\ ${ }^{2}$ Costal Water Fisheries Resources Research Division, National Institute of Fisheries Science, Busan 46083, Korea
}

Korea's fisheries science research began in 1921 at the Fisheries Experiment Station established during the Japanese colonial periods. Japan launched the station to plunder Korea's fisheries resources (NFRDI, 2001). After the liberation, the nation had to start rebuilding the country based on the poor infrastructure with heart-breaking history. But since then, nation's only fisheries research institute, the National Institute of Fisheries Science (NIFS), has been established and has promoted the development of fisheries technology and industry, Korea’s fisheries industry has been on par with advanced countries.

As we look back over the past century of the Korean fisheries science research, the initial stage of research started with basic oceanographic observations and fishery surveys in the 1920's. From 1930's up until the end of the Japanese colonial periods, Japan investigated fisheries resources on the coasts of Korea for the purpose of procuring war supplies. From the late 1940's to the 1950's, after the liberation, the dissemination of agar manufacturing technology has promoted the Korean export industry, accounting for 20 percent of the nation's total exports (NIFS, 2019). In the 1960's, the emergence of Korean distant-water fisheries such as tuna fishing (MSIT, 2015) and the development and dissemination of shellfish and seaweed farming technologies, including oyster, clams, laver, and sea mustard, increased the seafood production and export, building a solid basis for the Korean economy (Bae, 1985). Fisheries science research has further advanced since the 1970's, where the development of hygiene management and processing technologies of fisheries products have accelerate the shellfish export, and researches on stow net and anchovy tow net fisheries enabled a significant cost reduction (NIFS, 2019). Since the 1980's, starting with the development of flounder farming technology, hard efforts have been made to develop aquaculture technologies for a variety of aquatic organisms, such as olive flounder and abalone (Park \& Kim, 2013), according to the government's fish farming development policy. In particular, in the 1990's, our research capability has expanded to address marine environmental issues, developing monitoring technologies and preventive measures in response to a mass occurrence of harmful aquatic organisms such as red algae. In the 2000's, NIFS has led the development of high-tech aquaculture technologies by developing

Received: Aug 6, 2021 Revised: Aug 10, 2021 Accepted: Aug 26, 2021

*Corresponding author: Kyoungmi Won

Research Planning Division, National Institute of Fisheries Science, Busan 46083, Korea

Tel: +82-51-720-2842, Fax: +82-51-720-2828, E-mail: kyoungmiwon@korea.kr

*Corresponding author: Yeonghye Kim

Costal Water Fisheries Resources Research Division, National Institute of Fisheries Science, Busan 46083, Korea

Tel: +82-51-720-2291, Fax: +82-51-720-2277, E-mail: fishmail@korea.kr

This is an Open Access article distributed under the terms of the Creative Commons Attribution Non-Commercial License (http://creativecommons.org/licenses/by$\mathrm{nc} / 4.0 /$ ) which permits unrestricted non-commercial use, distribution, and reproduction in any medium, provided the original work is properly cited.

Copyright $\odot 2021$ The Korean Society of Fisheries and Aquatic Science 
high-quality species through selective breeding (Hwang \& Myeong, 2010), eco-friendly BioFloc technology (Cho et al., 2010), and vaccines against aquatic diseases (Hwang et al., 2020).

For a century, the fisheries science research in Korea has produced remarkable achievements. We have tried to accomplish this in the following sectors:

- Management of fisheries resources and development of fisheries engineering technology

- Research on the conservation of marine ecosystems

- Development of aquaculture technology and biotechnology

- Research on seafood safety and the control of aquatic life diseases

This special issue of FAS (Fisheries and aquatic sciences) includes 8 papers represented above sector.

In the first sector, we have tried to strike a balance between conservation of the fisheries resource and enhancement of the catch efficiency using the engineering technology, Hwang et al. (2021) present the reproductive behaviour, egg and larval development of short ninespine stickleback, Pungitius kaibarae. To reveal the physiological and ecological characteristics of aquatic animal is very important to conserve the fisheries resource. The other authors, Koo et al. (2021) compare the live shrimp bait on the catch efficiency in single line fishery.

In the following sector, conservation of marine ecosystem, the study on the assessment of marine environmental impact was selected, Oh et al. (2021) present a review for the he assessment of marine environmental impact of offshore wind power farm on fisheries. The study shows reasonable evidence that offshore wind power farm could been exposed to the considerable conflict with local fisheries.

In the next sector, aquaculture technique and biotechnology, there are 3 papers.

The Food and Agriculture Organization of the United Nations (FAO) reported that global capture fisheries and aquaculture production in 2018 were 96.4 and 82.1 (million $\mathrm{mt}$ ), respectively (FAO, 2020). Aquaculture now provides about $50 \%$ of consumable aquatic products, accounting for almost half of the world's fish supply. Aquaculture is also a very important and well-established sector in Korea.

The first authors, Han et al. (2021), present the effect on the growth of cultured abalone (Haliotis discus hannai) by adherent organisms such as pacific oyster, Crassostrea gigas, barnacle, Chthalamus spp., hydroid warm, etc. on the shell. The second au- thors, Yoo et al. (2021), introduce an application of the inorganic adsorbents such as Song-Gang bio-stone in the aquaculture industry. Biotechnology also contributes to the development of aquaculture research, including the investigation of immune gene expression from olive flounder, Paralichthys olivaceus (Kim et al., 2021b).

Lastly, the seafood safety and control of aquatic life diseases sector is also very important, Lee et al. (2021) provide to the information on the neurotoxins involved in shellfish and puffer fish poisoning such as paralytic shellfish toxins (PSTs) and tetrodotoxin (TTX). Experiments show that the toxicity of Koran pufferfish, Takifugu pardalis and Takihugu niphobles from the southern coast of Korea is due mainly to TTX. The other authors, Kim et al. (2021a) suggest the novel technique to detection and quantitation of red seabream iridovirus (RSIV) that is the principle infectious disease in the aquaculture system. It would be fair to say that these advanced techniques anticipate development of the aquaculture industry.

Korea's fisheries industry faces challenges, including climate change, decrease in offshore fishing production, deterioration of fishing ground, and strengthened international fisheries management regulations. It is time to gather our wisdom to solve the challenges in the fisheries industry. The articles presented in this special issue exemplify this. We hope that this issue will contribute to building a good foundation for Korea's fisheries industry to grow as a strong pillar of the national economy, not as a traditional industry in decline, but as a high-tech and high value-added industry. Finally, we hope these numerous researches lead the next 100 years based on the past century.

\section{Competing interests}

No potential conflict of interest relevant to this article was reported.

\section{Funding sources}

Not applicable.

\section{Acknowledgements}

This work was supported by a grant from the National Institute of Fisheries Science, Korea (Grant no. R2021069).

\section{Availability of data and materials}

Not applicable. 


\section{Ethics approval and consent to participate}

Not applicable.

\section{ORCID}

Kyoungmi Won https://orcid.org/0000-0003-3276-717X

Yeonghye Kim https://orcid.org/0000-0001-7282-4349

\section{References}

Bae SH. Development of oyster culture industry in Korea. Korean J Fish Aquat Sci. 1985;18:180-94.

Cho YR, Kim BR, Jang IK. Super-intensive culture of whiteleg shrimp, Litopenaeus vannamei (Boone, 1931), in HDPElined ponds with no water exchange. Korean J Fish Aquat Sci. 2010;43:331-9.

Food and Agriculture Organization of the United Nations [FAO]. The state of world fisheries and aquaculture [Internet]. 2020 [cited 2021 July 30]. http://www.fao.org/3/ ca9229en/CA9229EN.pdf

Han J, Jeon MA, Kim DW, Park H, Kim BH, Lee DC, et al. Growth of abalone (Haliotis discus hannai) in cages using epibiont control measures. Fish Aquat Sci. 2021;24:400-5.

Hwang IJ, Lee SW, Han YS, Kim KH. Reproductive characteristics, egg and larval development of short ninespine stickleback, Pungitius kaibarae. Fish Aquat Sci. 2021;24:375-82.

Hwang JW, Myeong JI. An economic effect of the selective breeding program on the oliver flounder aquaculture. J Fish Bus Adm. 2010;41:113-28.

Hwang JY, Kwon MG, Seo JS, Hwang SD, Jeong JM, Lee JH, et al. Current use and management of commercial fish vaccines in Korea. Fish Shellfish Immunol. 2020;102:20-7.

Kim GH, Kim MJ, Choi HJ, Koo MJ, Kim MJ, Min JG, et al. Evaluation of a novel TaqMan probe-based real-time polymerase chain reaction (PCR) assay for detection and quantitation of red sea bream iridovirus. Fish Aquat Sci. 2021a;24:351-9.

Kim JW, Cho JY, Chun WK, Kim DG, Nam BH, Nho ES, et al. Investigation of gene expression in primary embryonic cell line (FGBC8) from olive flounder Paralichthys olivaceus. Fish Aquat Sci. 2021b;24:370-4.

Koo M, Ishizaki M, Cho S, Bae B, Cha B. Comparison of live shrimp bait catch efficiency in single line fishery. Fish Aquat Sci. 2021;24:383-9.

Lee KJ, Ha KS, Jung YJ, Mok JS, Son KT, Lee HC, et al. Paralytic shellfish toxins (PSTs) and tetrodotoxin (TTX) of Korean pufferfish. Fish Aquat Sci. 2021;24:360-9.

Ministry of Science, ICT and Future Planning [MSIT]. The 70 great representative achievement of scientific technology (70th anniversary of liberation). Sejong, Korea: MSIT; 2015. p. 10-1, 74-5.

National Institute of Fisheries Science [NIFS]. History of the research on Korean fishery processing and hygiene. Busan, Korea: NIFS; 2019.

National Fisheries Research and Development Institute [NFRDI]. The 80 years of NFRDI history. Busan, Korea: NFRDI; 2001.

Oh HT, Chung Y, Jeon G, Shim J. Review of the marine environmental impact assessment reports regarding offshore wind farm. Fish Aquat Sci. 2021;24:341-50.Park CJ, Kim SY. Abalone aquaculture in Korea. J Shellfish Res. 2013;32:17-9.

Yoo G, Abediostad Z, Choi W, Bae J, Choi YH, Lee S, et al. Beneficial roles of Song-Gang stone as a feed additive in aquaculture: a review. Fish Aquat Sci. 2021;24:394-9. 